\title{
Internet Access on the Cheap: The Power of the Co-Op
}

\author{
Sorin Gudea \\ University of Phoenix, United States
}

\begin{abstract}
Internet access in the former socialist block continues to lag behind more developed countries. Unequal access to Information Technology has produced uneven levels of participation in the networked economy and society. Internet access, which is important to maintaining a technologically competent labour force, is a staple in the developed countries. However, it continues to be limited in Romania. Would-be users are devising inventive solutions to the relatively costly access solutions in order to get on the Information Highway. A country case study of Internet access in Romania reveals the advent of self-established, cooperative networks providing shared Internet access - seemingly a unique and innovative approach. Several of the Internet access plans on the market are presented in this paper together with a discussion of cyber cafés and the home-grown, co-operative networks that seem to be popping up all over the country. Understanding the context within which these home-grown networks arise and prosper offers valuable lessons and ideas for transferring these approaches to other developing countries that, like Romania, are struggling to bridge the infamous digital divide.
\end{abstract}

\section{Keywords}

Shared Internet access, Internet café, home-grown networks, digital divide

\section{Introduction}

The Internet is at the core of the information technology revolution and the global economy. It allows everyone with a personal computer to communicate with all other computers connected to it, worldwide. Significant differences exist in terms of ability to access the Internet as economic factors bear heavily on the issue. The cost of the personal computer and the recurring costs related to Internet access can be a major burden for some end users. That being said, the Internet is slowly taking off in the countries of the former socialist block. Yet, connecting to the Internet remains a costly endeavour for the majority of the population. As the world economy continues its push toward globalization, those countries that are slow to embrace the Internet face the unpleasant prospects of being left behind.

Romania is located in South-eastern Europe, bordering the Black Sea. Its largest neighbours are Bulgaria in the South and Ukraine in the North. Romania began its transition from Communism in 1989, but a largely obsolete industrial base and communications infrastructure have complicated its

Copyright (C) 2007 Victoria University. This document has been published as part of the Journal of Business Systems, Governance and Ethics in both online and print formats. Educational and non-profit institutions are granted a nonexclusive licence to utilise this document in whole or in part for personal or classroom use without fee, provided that correct attribution and citation are made and this copyright statement is reproduced. Any other usage is prohibited without the express permission of the efforts toward a market economy. In 2000 the country emerged from a three-year recession. There are palpable gains in privatization, deficit reduction, and inflation control. The Gross Domestic Product (GDP) per capita was $\$ 6,900$ in 2003 , with a growth rate of $4.5 \%$. The inflation rate in 2003 was $15 \%$. The International Monetary Fund predicts GDP changes of $4.4 \%$ for 2006 and $5.5 \%$ in 2007 , with consumer 
prices changing at rates of $7.8 \%$ and $5.7 \%$ respectively (IMF 2006).

The currency exchange rate reported for 2003 is 33,200 Lei (ROL) per US dollar (USD) (CIA 2004).

\section{Literature Review}

There is a notable lack of studies in academic journals regarding Internet access in Romania. The researcher was able to find only a few articles in practitioner magazines on this very topic. Goodman (1991) referred to the economic wasteland and old technology, remnants of the communist regime that ruled the country for forty-four years. Yet, there is a wealth of information available about Internet in Europe (Rocks 1998). However, the more detailed reports are only available from market research groups, and the associated fees were out of the reach of this study (Budd 2003).

Early references to Internet use in Romania go back to the early 1990s (Woodard 1995). Romania, like other Eastern European countries, lags behind in the number of broadband subscribers when compared to other more developed countries such as France, Germany, or the UK (Business Wire 2004). Yet, the countries of Eastern Europe have been surprisingly aggressive in adopting new technology. Eastern Europe had about 50 million mobile phone connections by the end of 2001, and a predicted annual growth rate of 16 percent (Ignatius 2002).

The new technologies installed in Eastern Europe are noteworthy. As early as 1998, Romania contracted with Cisco and BreezeCOM the upgrade of the Higher Education Network (RoEduNet), a national networking backbone with major nodes in six cities and links to all the country's universities as well as the non-profit scientific and cultural institutions (Business Wire 1998).

Internet usage in Romania continues to increase. The growth rate went from $10 \%$ in 2000 to $51 \%$ in 2004 (BBC Monitoring Media 2000; Tarifica Alert 2005). Yet progress is slow, especially when considering the relatively low GDP, low broadband DSL and cable TV penetration, and market liberalization and competition. The majority of Internet users are the staff of the companies that have access to the Internet at the office and the owners of personal computers, whose numbers are on the rise (BBC Monitoring Media 2000)

By 2007, when it is conditionally scheduled to join the European Union (EU), Romania was forecast to have an online population of around 3 million people, yet achieve the lowest online penetration rate in the EU, at just over $12 \%$. Online spending will grow at a much faster rate, as users become more mature and therefore spend more online. Offline spending power will likely increase with accession to the EU, and as more online retail opportunities open up, with more companies operating Web sites in these countries (MacAonghus 2004).

\section{Communications Infrastructure}

Economic improvements in Romania have lead to a gradual increase in wages. Yet, in relative terms, Internet access is anything but affordable. Affordability is an important factor that can hinder Internet use. Given the relatively low GDP in Romania, individuals, educational establishments and small business cannot afford significant Information and Communication Technology (ICT) expenditures. It is only natural then to find that broadband Internet access, Internet services and e- commerce are in their infancy in this geographic area (M2 PressWire 2003).

Internet access requires an adequate communications infrastructure. In Romania, the communications infrastructure includes 4.3 million telephones, and 6.9 million cellular phones (CIA 2004). The telephone system is assessed as rather poor, yet improving. Ninety percent of the domestic telephone network is automatic. Trunk network is mostly microwave radio relay, with some fibre-optic cable. About one third of the exchange capacity is digital. Reports show that in 2004 there were 201 mobile radio communications providers, 142 local telephony providers and 163 international calling service providers (Tarifica Alert 2004). 
The internet country code is ".ro" and approximately 51,000 Internet hosts were online in 2004 - up from only 20 in October 1993 (RomaniaBusiness.com 1997). Things are changing rapidly with the majority of educational institutions, government, and non-government organizations (NGOs) establishing an Internet presence. There are more than 40 newspapers and 4 TV stations offering Internet programs (Jalobeanu 2003).

During the socialist era, Romania, like the rest of the socialist countries, fell behind in terms of data and telecommunications technology. Since 1989, when Romania turned toward a market economy, significant progress has been made. The telecommunication infrastructure continues to modernize, with most of the exchanges (Central Offices or COs) now being digital. Yet, there is a significant number of analog COs still in operation. This impacts the availability and quality of dial-up service and of digital data transmission.

Published figures for 2000 show that Romania had 7.5 million households and approximately 400,000 personal computers (a penetration rate of $7 \%$ ). Approximately 15 to $20 \%$ of these PCs are connected to networks and 3 to $4 \%$ are connected to the Internet. There were approximately 250 Internet Service Providers (ISP) and some 70,000 Internet users. Romanian ISPs, independent companies from RomTelecom, are trying to gain national coverage. Due to competition the tariff for Internet access decreased by half in 1999. A typical dial-up Internet users (20 hours per month) pays an average of US\$35 a month, of which as much as US\$24 may account for telephone service.

In 2002, Romania had only twenty one secure servers, as compared to Croatia (25), Bulgaria (10) and Yugoslavia (7). Romania benefits from the deployment of two public networks: The Romanian Education Network and the Romanian National Computer Network. In terms of international connectivity, Romania has direct fiber optic links with European backbones and operates the only Internet Exchange in the region, based in Bucharest (Gurau 2002).

In Eastern Europe low per-capita-income levels and less spending on computers in general are responsible for a low Internet penetration rate: around $10 \%$ in 2003 , compared to $35 \%$ in the EU. For comparison, the Internet penetration rate in U.S. households was 64\% (Ladika 2004). To the average Romanian Internet user mentioned earlier, the US\$35 he spend to access the Internet can easily account for 30 to $35 \%$ of his wages (Oaca 2000).

\section{Market}

The market for Internet services in Romania is estimated at $\$ 6$ million per year, in 2004. This is a relatively small number in comparison to neighbouring countries such as Hungary ( $\$ 800$ million/year) or the Czech Republic (\$1.6 billion/ year) (Telelucru 2004).

For Romania, estimates of the number of personal computers in existence vary. One source reported ten personal computers per thousand and Internet access penetration of 9.01 per 10,000 (LearnLink 2002). Another source reported 880,000 PCs overall and Internet access penetration of $4.4 \%$ for the same year - 2002 (Noua Economie 2002). While these reports differ, even the lowest figures show a marked improvement over 2000 when, according to Norris, less than .5\% of the population was online (Norris 2000).

The average monthly wage is about $€ 150$, which is approximately $\$ 190$ at the current (September 2006) exchange rate. With the cost of a typical personal computer of $\$ 600-700$, it should come as no surprise that those who use computers mainly at the office outnumber those who use computers at home by a 2:1 margin (Noua Economie 2002).

A comparison of Internet access penetration rates among Romania, Hungary, and three developed countries (UK, France, USA) show significant differences. Namely, Internet access penetration in Romania is much lower. In 2001 Romania had a 4.4\% Internet penetration rate, while U.K. had 55\%, France 28\%, and USA 51\% (Eurostat 2004). Mainly due to the low-income levels in all East European countries, fixed-line, Internet and mobile penetration rates are all low. Broadband Internet access is 
available in several countries but subscriber numbers are minimal (Business Wire 2004). The situation has improved significantly over the past few years (Figure 1). Recent (2007) statistics show significant increase in Internet penetration in Romania, as high as 517\% during 2000-2007 (Internet World Stats 2007; Internet World Stats 2007).

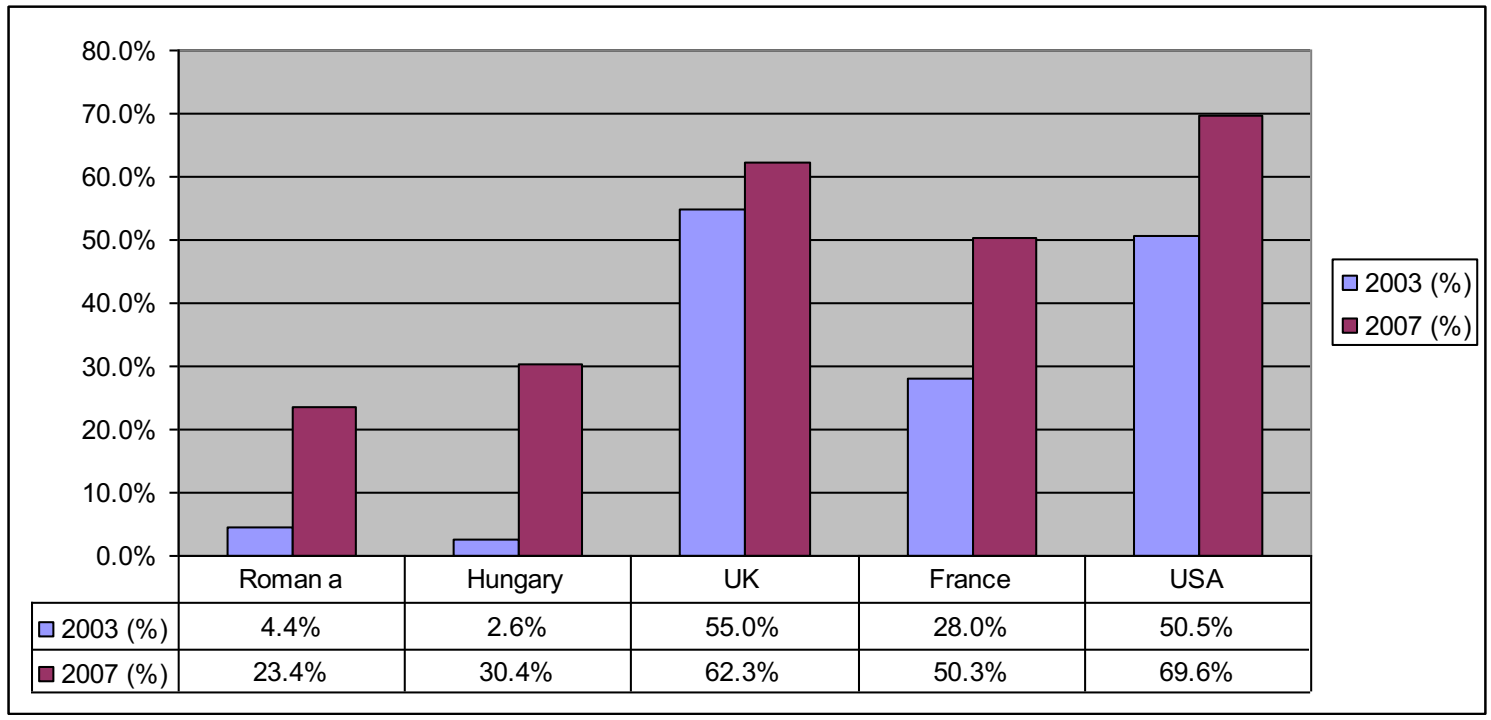

Figure 1. Internet access penetration - 2007 v. $2003(\%)$

Consumers have the choice of either dial-up or broadband Internet access plans. For tasks such as online chat or email, a dial-up connection would be sufficient for most users. Users that require access to multimedia and online games may consider a broadband connection as it would offer better performance. In addition to contracted Internet access, there are numerous cyber cafés that offer a convenient, affordable path to the Internet. Furthermore, innovative solutions involving shared Internet access over a home-made local area network are cropping up, in particular in the cities, where apartment buildings are common.

\section{Digital Divide}

In the information society, knowledge and information constitute fundamental sources of access to information that leads to well-being and progress. Highly-developed ICT networks, equitable access to information, appropriate content in accessible formats and effective communication can help people achieve their potential, promote sustainable economic and social development, and improve the quality of life for all (M2 PressWire 2003).

ICTs enable societies to promote sustainable growth, advance social justice and strengthen democratic governance (Johnson 1999). The widening digital gap between rich and poor and unequal access to ICTs had produced uneven levels of participation in the networked economy and society.

The expansion of Internet usage in Romania makes e-governance possible and necessary. The Government was committed to ICT and e-initiatives, in order to better fulfil its obligations, particularly in areas of education, social protection, the promotion of economic growth and ensuring free access to competitive markets. Providing such services on-line would encourage better integration of ICT in and among local communities and boost infrastructure development as well. Two such projects under way were on-line tax payment and e-procurement, to ensure transparency and efficiency in the public procurement process (M2 PressWire 2002).

Internet access, which is important to maintaining a technologically competent labour force, is still very limited in Romania (OxResearch 2002). There is a digital divide between Eastern and Western Europe. Many potential customers are thought to be deterred by the high costs currently associated with dial-up internet access, in turn reflecting the monopolies which national telecommunication firms retain over 
fixed-line networks (Chandler 2002). It is no surprise that the United Nations is trying to help by sending consultants into Romania to expand access to the Internet (Chronicle 2001). In fact, the Bill and Melinda Gates Foundation announced a project to install computers and provide free Internet access in Romania's public libraries (The Age 2006).

Governmental agencies are hard at work: in 2001 the Romanian government was investing in ICT, school computerization and schools' access to the internet (BBC Monitoring European - Political 2001). In addition, The Romanian Group for Promoting Information Technology was to launch 24 e-projects in 2001 including developing "Romanian Gateway" to promote industry and raise the country's profile, providing computer and Internet access in over 17,000 schools, a site for filling in customs documents online and provisions for allowing people to express their opinions online in an Electronic Referendum service (The Electronic Library 2001).

The use of the Internet has also increased. In 2004 in Romania there were approximately 40 large ISPs with one million Internet subscribers, most of whom use dial-up modems that provide low rates of data transfer. Although many academic sites have higher-capacity ISDN connections to the Internet, the data rates are still limited to 128 or 256 kbit/s (Panait, Doarn, Saftoiu, Popovici, Valeanu and Merrell 2004).

Notably, there are business initiatives in place geared toward providing telemedicine and banking services. Although telemedicine is currently practiced in Romania, there are barriers to its further development and widespread implementation. These include the outdated infrastructure for telecommunications and for Internet access, and the limited availability of modern PCs and digital medical equipment. However, the medical equipment is slowly being upgraded, especially in the large university centres, and this is creating the opportunity to establish centers of telemedicine expertise. The key to fulfilling such a vision is to obtain funding. To be effective at the national level, a coherent effort in telemedicine must be made. This requires government awareness and support (Panait, Doarn et al. 2004).

The successful implementation and development of online banking are influenced by many inter-related factors and institutions, including the quality and security of Internet network, the level of Internet knowledge of the population, the government support, as well as the Internet strategy of the bank and the quality/reliability of online banking services (Gurau 2002). Furthermore, most users have only limited online experience and therefore will be less likely to shop, since shoppers tend to be mature users. And with income levels far below those of many EU members, online spending is set to remain low (EuropeMedia 2003).

\section{Research Questions}

Participation in the digital economy is no longer a luxury in the developed world. As the literature review shows, there are economic forces at play which prevents wide-spread access to the Internet. Given the low per capita income and the relatively high Internet access fees, the low market penetration of the Internet in Romania should come as no surprise. This study sought to investigate the connectivity options available to the Romanian would-be Internet surfer. A second research question was to find out whether the economic and technological hindrances - characteristics of a developing country - can be circumvented, and if so, in what manner.

\section{Research Framework}

Innovation and entrepreneurship are characteristics of the human species. In order to be able to reap the advantages offered by the Internet, one must first find a way to connect to it. Novel, cost-effective access solutions are evidence of innovation; that is, in Rogers' words “... an idea, practice, or object that is perceived as new by an individual" (Rogers, 1995, p.11). The Diffusion of Innovations theory asserts there are four factors recognized to influence the adoption of innovation: the innovation itself, the channels used to spread information about the innovation, time, and the nature of the society where the innovation is introduced (Rogers 1995). 
Within the framework of the Diffusion of Innovations theory, the co-operative Internet access solution unveiled by this study is a technological innovation because it is considered to be a new idea by potential adopters. The merits of the innovation - lower Internet access fees, better bandwidth, or even access at all - are appealing to Internet users. The communication channels supporting its diffusion are more often than not interpersonal communication, which Rogers (1995) qualifies as most effective in persuading potential adopters. The potential for adoption is further increased with face-to-face communication among individuals that share the same social and economic status, and level of education (Rogers 1995).

A second theory relevant to this study is Rogers' Innovation Decision Process Theory (Rogers 1995). The theory defines diffusion as the process by which members of a certain community embrace and adopt innovation. Rogers (1995) asserts that five different stages are involved. First, the potential adopters must learn about the innovation. Second, they must be persuaded and become convinced of the merits of the particular innovation. Third, they must decide to adopt the innovation. Fourth, they must actually implement the innovation. And last, they must confirm their decision to adopt the innovation was correct. Once all these stages are achieved, then diffusion results (Rogers 1995).

In the context of this study, potential adopters learn about the co-operative Internet access devised and employed by other Internet users and are persuaded by the economic benefits offered by the innovation. They next adopt and implement the innovation, by either joining an existing co-op (home-grown network) or starting their own. As they begin to enjoy the lower costs and/or higher bandwidth, in agreement with Rogers, diffusion has taken place. Rogers (1995) states that an increased rate of adoption is predicated upon the innovation having a relative advantage, compatibility with existing values and past experiences, relatively low complexity, trial-ability, and observability. The co-operative Internet access solution described in the study meets these requirements as it offers superior economics (relative advantage), offers the same type of Internet experience (compatibility with existing experiences), has relatively low complexity, it can be tried hands-on (trial-ability), and is readily observable both in terms of costs and bandwidth available (i.e., benefits).

The theoretical framework offered above is relevant to the context of the study in that, as this study unveiled, innovative responses to the relatively high ISP fees are devised and adopted by some Internet users. As stated earlier, the study set out to explore the various means for Internet access available to would-be Internet surfers in Romania - a developing economy. The researcher found that the innovation - the co-operative, shared Internet access that centers on home-grown local area networks - offers a viable, economically appealing alternative to individual Internet access accounts.

The findings from the study suggest that innovation is hard at work in Romania. The analysis of the data available from the study and the brief interviews with several Internet users reveal the advent of the home-grown, co-operative networks with shared Internet access. The following sections of the paper discuss these findings in detail. The insights are relevant to other developing economies and to Internet users who are looking for ways to mitigate the economic impact of relatively high Internet access fees.

\section{Methodology}

The researcher chose a case study approach to investigate the phenomenon of interest (Yin 1994). Given the scope of the investigation in a national setting and the exploratory orientation of the study, the researcher resorted to analysing public documents available over the Internet. The data collection was augmented by personal communications and interviews with several Internet users in Romania, who shared their experiences connecting to the Internet. The respondent sample is small; it consisted of 11 participants (five females and six males) from two different co-ops. The youngest person interviewed was seventeen years old, and the oldest one thirty-four. The in-person interviews were conducted over a period of two weeks, and involved unstructured, open-ended questions. When online, the majority of the respondents spent their time in chat rooms and playing online games, taking advantage of the greater bandwidth available through the co-op. While hardly a representative sample, the respondents help validate the findings of the study. 
In order to improve the validity and reliability of the study, the researcher followed a triangulation strategy. Multiple sources of evidence were used, involving mainly analysis of existing documentation in both print and electronic form. This combined approach to data collection supports the internal validity of the study. In general, external validity is more difficult to attain in single-case study. Yet, the study informs on Internet access solutions in Romania and it discovered an innovative approach to reducing the Internet access fees to a more affordable level. The findings are relevant to researchers and practitioners interested in the social and economical aspects related to Internet penetration in Eastern Europe. In addition, important lessons can be learned and are applicable to other developing countries that share the same type of economical issues. Namely, the low per capita income and relatively high Internet access fees.

\section{Findings}

The results of the study offer a glimmer of hope for those who, while economically disadvantaged, wish to be able to surf the Web. A review of the ISPs that operate in Romania, complete with pricing structure, bandwidth and level of service is presented in the following section. In conjunction with the economic environment discussed in the previous sections, this study offers an understanding of the costs associated with Internet access and informs on what Romanian Internet users are facing. The advent of the Internet cafés and of the co-operative approach to Internet access is discussed. The former offers affordable Internet access to those who either lack a personal computer, or may be away from their home or office. The latter represents an innovative solution to what otherwise may be an economically intractable problem for the less affluent user who owns a personal computer: making Internet access more affordable.

\section{Internet Service Providers}

Romania started connecting to the Internet in 1992 (Jalobeanu 2003). In 1993 there were only three ISPs: Eunet (KPNQWest), Starnets (Euroweb), and PCNET, yet Romania kept pace with the explosion of the World Wide Web. In 1999, the most important players were: Global One Communications Romania; Logic Telecom, which in 1996 established a subsidiary in Moldova; StarNet (with 8,500 subscribers), Dynamic Network Technologies (8,500 users), PC-Net (18,000 users), RNC (10,000 users), FX (8,500 users), and RoEduNet - the network of the Romanian educational system and ICI which operates the network of Romanian research institutes (Oaca 2000).

In 2002 Internet access was offered by 38 Internet Service Providers (Noua Economie 2002). By 2004, there were 498 service providers in Romania that offered data services and 570 Internet service providers (Tarifica Alert 2004). Today, Internet access is offered via dial-up (ISDN, $33.6 \mathrm{kbps}, 28.8$ kbps, 56 kbps), leased lines (nx64K, E1, T1, T3, Frame Relay, DSL, ATM), and broadband (DSL, ADSL, Cable, Fixed Wireless, Satellite) (ANISP Romania 2003).

\section{Dial-up Service}

The most common Internet access modality is dial-up. Yet, unlike in more developed countries such as USA, Canada, etc., where local calls are generally billed at a fixed rate (included in the monthly fees paid to the local phone company), in Romania, just as in the majority of the European countries, all calls incur charges by the minute. This adds to the cost of the Internet access.

In Western Europe (e.g., Germany, UK) data transmission can be contracted for a fixed monthly fee, from the local phone carrier. Yet this type of change is slow to take place in Romania despite the liberalization of the phone services in 2003. For a long time, all phone services was provided exclusively by ROMTELECOM. Aside from cellular carriers that provide mobile telephony service, the situation continues. None of the new entrants into the market has managed to secure a significant share of the fixed telephony market. Any company offering phone service over existing cabling that belongs to RomTelecom would have to pay access fees, making potential profits less appealing and more difficult 
to achieve. It is more lucrative for these companies to focus on offering long distance and international telephone service. Any company that tries to enter the market will face existing competition from established companies.

Telephone service fees vary during the day, and season. While customers in western European countries enjoy reduced telephone service tariffs during evening hours, this is not quite the case in Romania. Where and when such reduced tariffs are offered, the terms and conditions can vary significantly among providers.

In general, the rates for telephone service include a Value-Added Tax (VAT) of 19\%. These monies are submitted to the tax collector and benefit the government. The most common type of telephone service costs $\$ 7.00$ a month and includes $\$ 2.00$ worth of traffic. Some other types of service are available for lower rates, yet they have additional restrictions. As of June 1st, 2004, telephone service rates are subject to two-tiers, with lower rates being charged during evening hours - $\$ 0.041 / \mathrm{min}$ during business hours (workdays from 8:00am to $8: 00 \mathrm{pm}$ ) and $\$ 0.014 / \mathrm{min}$ for non-peak hours. Through ROMTELECOM, since 2001 it is possible to take advantage of a reduced rate applicable to data communications. However, this requires that telephone services be provided by a digital $\mathrm{CO}$, or that more sophisticated service monitoring options are to the subscriber. This is not always the case.

The access fees charged by Internet Service Providers vary. For example, customer located in the capital city, Bucharest, can choose from several plans that offer a limited number of hours (e.g., 5 hours for $\$ 1.19,20$ hours for $\$ 5.95$, or 100 hours for $\$ 16.66$ ). Subscription plans that offer unlimited service are somewhat more expensive, and range from $\$ 5.95 /$ month for non-peak access to $\$ 11.90 /$ month anytime. Billing and payment for the monthly service is done in advance (Table 1).

Table 1. Internet Service Providers - monthly access fees for limited dial-up access

\begin{tabular}{|l|l|l|l|l|l|l|l|l|l|l|}
\hline & $5 \mathrm{Hrs}$. & $6 . \mathrm{Hrs}$. & $10 \mathrm{Hrs}$. & $15 \mathrm{Hrs}$. & $20 \mathrm{Hrs}$. & $\begin{array}{l}25 \mathrm{Hrs} \\
.\end{array}$ & $\begin{array}{l}30 \mathrm{Hrs} \\
.\end{array}$ & $\begin{array}{l}50 \mathrm{Hrs} \\
.\end{array}$ & $\begin{array}{l}60 \mathrm{Hrs} \\
.\end{array}$ & $\begin{array}{l}100 \mathrm{Hrs} \\
.\end{array}$ \\
\hline RDS & & & $\$ 3.57$ & & & $\$ 4.76$ & & $\$ 7.14$ & & \\
\hline PCNET & $\$ 1, .19$ & & $\$ 2.38$ & & $\$ 4.76$ & & & $\$ 9.52$ & & $\$ 16.66$ \\
\hline FX & & & & & & & & & & \\
\hline ARTELECOM & & & & & & & & & & \\
\hline DIGICOM & & & & & $\$ 5.95$ & & & & & \\
\hline IDILIS* & & & & & & & $\$ 4.50$ & & $\$ 6.00$ & \\
\hline DIALPLUS** & & $\$ 1.19$ & & & $\$ 3.57$ & & & & & \\
\hline
\end{tabular}

* Requires purchase of an access card. ** Ordering through SMS; fees charged to a mobile phone account.

Certain subscription plans offer unlimited Internet access. A cost comparison of existing Internet access plans that offer unlimited access is presented in Table 2.

Table 2. Internet Service Providers - monthly access fees for unlimited dial-up access

\begin{tabular}{|l|l|l|l|}
\hline & Non-peak hours (7:00pm - 7:00am) & Any time & e-Mail only \\
\hline RDS & $\$ 5.95$ & $\$ 11.90$ & \\
\hline PCNET & $\$ 8.35$ & $\$ 10.71$ & \\
\hline FX & & $\$ 10.71$ & $\$ 21.42 /$ year \\
\hline ARTELECOM & $\$ 5.95$ & $\$ 8.33$ & \\
\hline DIGICOM & & $\$ 11.90$ & \\
\hline IDILIS* & & & $\$ 9.00$ \\
\hline
\end{tabular}

* Requires purchase of an access card.

Billing and payment for the monthly service is done in advance. A few Internet Service Providers offer access to the Internet without requiring a long-term commitment, or subscription - as shown in Table 3 . In such case, fees for the Internet access are billed on the phone invoice.

Table 3. Internet Service Providers - access fees without a subscription plan

\begin{tabular}{|l|l|l|}
\hline & Daytime access (peak hours) & Night time access (non-peak hours) \\
\hline IDILIS & $8: 00 \mathrm{am}-8: 00 \mathrm{pm}: \$ 0.27 / \mathrm{min}$. & $\$ 0.17 / \mathrm{min}$. \\
\hline WEBLINE & $8: 00 \mathrm{am}-8: 00 \mathrm{pm}: \$ 0.29 / \mathrm{min}$. & $\$ 0.17 / \mathrm{min}$. \\
\hline
\end{tabular}




\begin{tabular}{|l|l|l|}
\hline ARTEL & $8: 00 \mathrm{am}-8: 00 \mathrm{pm}: \$ 0.25 / \mathrm{min}$. & $\$ 0.12 / \mathrm{min}$. \\
\hline EASYNET & $8: 00 \mathrm{am}-10: 00 \mathrm{pm}: \$ 0.27 / \mathrm{min}$. & $\$ 0.17 / \mathrm{min}$. \\
\hline ROMTELECOM & $8: 00 \mathrm{am}-8: 00 \mathrm{pm}: \$ 0.81 / \mathrm{min}$ & $\$ 0.39 / \mathrm{min}$ (including weekends) \\
\hline
\end{tabular}

ISPs in general offer a fixed number of hours of access that typically expire within 30 days from purchase. They resort to innovative marketing campaigns and access packages to target in particular the younger customers. Unlimited monthly access plans are very common. Alternatively, access cards that offer one month of unlimited access can be purchased for approximately $\$ 9.00$. Other plans offer a limited number of hours (usually in multiples of five: 5, 10, 15, 20, etc.) of Internet access, or, limited access to email only (Munteanu 2004).

\section{Broadband Service}

A relatively small number of companies control the market. In September of 1999, an investment fund backed by EBRD paid $\$ 1.5$ million for a $40 \%$ stake in PC-Net, the first investment in a Romanian ISP (Oaca 2000). Over time, numerous mergers and acquisitions have taken place, leading to the current situation. Service areas do not overlap, and customers do not have a choice of cable providers.

Cable access to the Internet was, until 2002 a very expensive proposition. Prices began to drop after 2002 (EuropeMedia 2002). The abolition of the RomTelecom monopoly in the telephone services market, in 2003, should have helped the cable providers (The Electronic Library 2001). Yet, there was no significant effort on their behalf to modernize their cable plants, a requirement for offering phone and Internet services (Business Wire 1998; Munteanu 2004).

Broadband Internet access plans typically include a limited amount of traffic for a monthly fee (e.g., $\$ 10.71 /$ month with $1 \mathrm{~GB}$ traffic included - additional traffic is charges at $\$ 0.04 / \mathrm{MB}$ ). The broadband speed is between $128 \mathrm{kbps}$ and $256 \mathrm{kbps}$. Additional fees are incurred for installation, and for the modem (Business Eastern Europe 2002). Table 4 details some of the broadband Internet access offer.

In the second half of 2004, Internet access service bundles continued to evolve (e.g., the $\$ 10.71 /$ month agreement now allows $1 \mathrm{~GB}$ of traffic, up from $500 \mathrm{MB}$ ). Likewise, $\$ 17.85$ will allow $2.5 \mathrm{~GB} / \mathrm{month}$ (up from $1.5 \mathrm{~GB}$ ). The connection speed increased from $128 \mathrm{kbps}$ to a maximum of $256 \mathrm{kbps}$.

Table 4. Internet access plans - broadband

\begin{tabular}{|c|c|c|c|c|c|c|c|c|}
\hline ISP & Plan & Cost & Speed & $\begin{array}{l}\text { Traffic } \\
\text { Included }\end{array}$ & $\begin{array}{l}\text { Additional } \\
\text { Traffic }\end{array}$ & Installation & $\begin{array}{l}\text { Modem } \\
\text { cost }\end{array}$ & Notes \\
\hline \multirow[t]{8}{*}{ RDS } & CableLink + & $\$ 10.71$ & $256 \mathrm{kbps}$ & $1 \mathrm{~GB}$ & $\$ 0.04 / \mathrm{MB}$ & $\$ 17.85$ & 0 & $\begin{array}{ll}\begin{array}{l}\text { Requires cable } \\
\text { subscription }\end{array} & \text { TV } \\
\end{array}$ \\
\hline & & $\$ 17.85$ & & $2.5 \mathrm{~GB}$ & $\$ 0.02 / \mathrm{MB}$ & & & \\
\hline & & $\$ 23.80$ & & 4GB & $\$ 0.015 / \mathrm{MB}$ & & & \\
\hline & & $\$ 34.51$ & & $12 \mathrm{~GB}$ & $\$ 0.01 / \mathrm{MB}$ & & & \\
\hline & Cable Link & $\$ 17.25$ & & $1.1 \mathrm{~GB}$ & $\$ 0.04 / \mathrm{MB}$ & & & \\
\hline & & $\$ 24.39$ & & $2.6 \mathrm{~GB}$ & $\$ 0.02 / \mathrm{MB}$ & & & \\
\hline & & $\$ 30.34$ & & $4.2 \mathrm{~GB}$ & $\$ 0.015 / \mathrm{MB}$ & & & \\
\hline & & $\$ 41.05$ & & $12.5 \mathrm{~GB}$ & $\$ 0.01 / \mathrm{MB}$ & & & \\
\hline \multirow[t]{3}{*}{ ASTRAL } & Trafic & $\$ 22.61$ & & $600 \mathrm{MB}$ & $\$ 0.01 / \mathrm{MB}$ & $\$ 11.90$ & $\$ 101.15$ & Cable \\
\hline & Hobby & $\$ 28.56$ & & unlimited $^{*}$ & & & & $\begin{array}{l}\text { Unlimited traffic during } \\
\text { non-peak hours }(7: 00 \mathrm{pm} \\
-7: 00 \mathrm{am} \text { and weekends) }\end{array}$ \\
\hline & & $\$ 34.51$ & $128 \mathrm{kbps}$ & unlimited & & & & \\
\hline FX & & $\$ 34.51$ & $\begin{array}{l}64-256 \\
\text { kbps }\end{array}$ & $1 \mathrm{~GB}$ & $\begin{array}{l}\$ 17.85 / 500 \\
\mathrm{MB}\end{array}$ & $\$ 28.95$ & & Dial-up; cable; radio \\
\hline \multirow[t]{8}{*}{ ESS } & & $\$ 23.80$ & & $200 \mathrm{Mb}$ & $\$ 0.95 / \mathrm{MB}$ & $\$ 35.70$ & $\$ 142.80$ & Cable \\
\hline & & $\$ 59.50$ & & $600 \mathrm{MB}$ & $\$ 0.83 / \mathrm{MB}$ & & & \\
\hline & & $\$ 148.75$ & & $1.8 \mathrm{~GB}$ & $\$ 0.53 / \mathrm{MB}$ & & & \\
\hline & & $\$ 297.50$ & & $3.6 \mathrm{~GB}$ & $\$ 0.30 / \mathrm{MB}$ & & & \\
\hline & & $\$ 416.50$ & & $5 \mathrm{~GB}$ & $\$ 0.24 / \mathrm{MB}$ & & & \\
\hline & & $\$ 226.10$ & $64 \mathrm{kbps}$ & unlimited & & & & \\
\hline & & $\$ 386.75$ & $128 \mathrm{kbps}$ & unlimited & & & & \\
\hline & & $\$ 714.00$ & $256 \mathrm{kbps}$ & unlimited & & & & \\
\hline \multirow{2}{*}{$\begin{array}{l}\text { OPEN } \\
\text { SYSTEMS }\end{array}$} & & $\$ 14.28$ & & $1 \mathrm{~GB}$ & $\$ 0.12 / \mathrm{MB}$ & & & Cable \\
\hline & & $\$ 20.23$ & & unlimited ${ }^{*}$ & & & & Non-peak hours \\
\hline
\end{tabular}




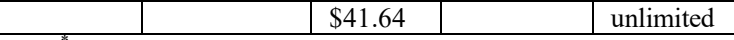

- during non-peak hours (workday evenings and the weekend)

\section{Internet Cafés}

A very popular and affordable means to the Internet is offered by Internet cafés. Typically these are set up in two or three-bedroom apartments, almost always on the ground floor with easy access from the street. In general, there is no coffee served at these establishments. A typical Internet café has between ten and twenty networked computers sharing an Internet connection - usually broadband. The computers are of various vintage, often built using salvaged components. Additional services that may be available to customers are internet telephony, email, chat, software and media downloads, print and fax services.

The Internet Café is a resource that provides support for, and serves the entertainment, business and communication needs of individual consumers - those who cannot afford Internet access from their own homes, and the occasional tourist. Internet cafés are attractive in that they represent economic opportunity for the owner. Thus, they are "for profit" enterprises and must sustain a profit. Would-be Internet surfers pay an hourly rate and can use a PC to access the Internet. The fees are between $\$ 0.50$ $\$ 1.00$ per hour. One source put the number of Internet cafés (cyber-cafés) in Romania at 18 in 2004. At the beginning of 2007 there were approximately 58 such cyber cafés advertised online (Afla.ro 2007; Cybercafes.com 2007; Romania-On-Line 2007; World66.com 2007). While indicating growth, none of these numbers would appear to adequately reflect the popularity of these establishments. Anecdotal evidence indicates the real number is much higher, perhaps by as much as a factor or 10 across the entire country.

\section{Home-grown Shared Internet Access}

A notable trend is the development of private, neighbourhood-, peer access networks. As it seems, this novel, innovative approach is unique and has not been encountered or reported elsewhere. Typically, one or more ISP accounts are set up and shared among a number of participants that share the costs equally. This results in a decent quality connection at an excellent price - clearly, a better value. These private networks may cache popular sites (e.g., games, movies, shareware software). Aside from providing Internet access, these networks take advantage of the higher speed available on the ISP's internal network (the term metropolitan access is used) and offer online gaming, chat and email services to their members.

The high cost associated with Internet access has motivated would-be users to organize and build their own local networks, connecting to the Internet through a shared account. The end users interviewed reveal two basic approaches to establishing a home-grown network. Frequently it starts with one user who purchases Internet access from a local ISP and pays the necessary fees. This person would next enrol other users and build a local area network using whatever parts and components can be procured (Figure 2). Consequently, the home-grown network could be either wired (Ethernet - with different connection rates) or wireless. As the number of users connected to the network grows, more money become available and would go towards higher bandwidth from the ISP as well as network wiring and equipment upgrades.

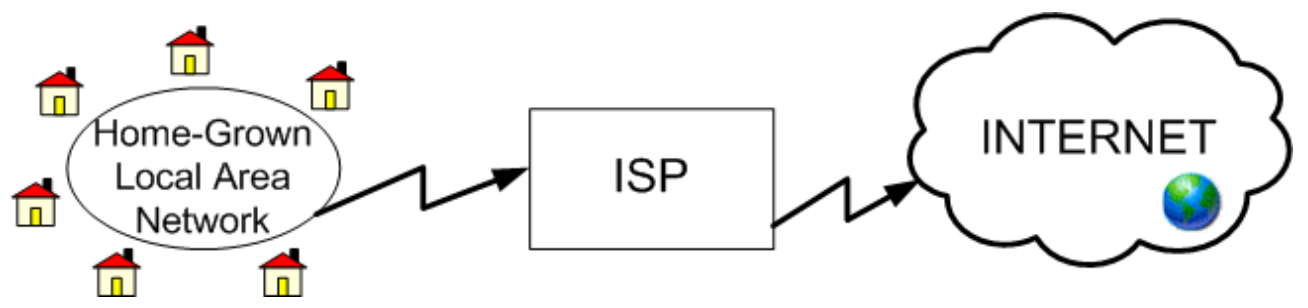

Figure 2. Home-Grown Local Area Network 
Alternatively, it could be a group of neighbours who decide to pool their resources and share the cost of the Internet service. They will then build the local area network and share the benefits it yields: lower Internet access fees per user, a local online community in which they are members, and as more monies become available, higher bandwidth from the ISP and network upgrades.

While mainly in the cities, these home-grown networks have become quite popular lately. Table 5 shows where some of these home-grown networks are located. Aside from offering Internet access, these networks also allow shared games, chat, file downloads, etc. This type of setup offers access to a superior Internet connection (in terms of connection speed and amount of traffic allowed) for a reasonable price. Reportedly there were 116 such networks with approximately 12,000 users at the end of 2004 (DAP 2004; Home.ro 2004).

Table 5. Home-grown networks

\begin{tabular}{|c|c|c|c|c|c|}
\hline \multirow[b]{2}{*}{ Location } & \multicolumn{2}{|c|}{ \# of networks } & \multirow[b]{2}{*}{ Location } & \multicolumn{2}{|c|}{ \# of networks } \\
\hline & 2004 & 2007 & & 2004 & 2007 \\
\hline Arad & 1 & 8 & Iasi & 1 & 20 \\
\hline Bucuresti & 74 & 383 & Oradea & 3 & 5 \\
\hline Brasov & 4 & 15 & Pitesti & 6 & 15 \\
\hline Buzau & 2 & 14 & Ploiesti & 3 & 24 \\
\hline Cluj & 1 & 18 & Sibiu & 3 & 6 \\
\hline Constanta & 2 & 17 & Targu-Jiu & 1 & 5 \\
\hline Craiova & 1 & 1 & Timisoara & 5 & 24 \\
\hline Focsani & 1 & 3 & Vaslui & 1 & 7 \\
\hline Galati & 4 & 38 & Zalau & 1 & 5 \\
\hline
\end{tabular}

The situation evolved overtime. As more people became interested in becoming part of the home-grown network phenomenon, the numbers went up. In January 2007 Romania had 699 such home-grown networks, totalling over 1.6 million users. While the number of home-grown networks grew from 116 to 699 (a $600 \%$ increase), the number of members/subscribers grew from 12,000 to 1,637,814 (a 13,648\% increase) over two years. In addition, these home grown networks can be found in 40 cities in 2007, up from only 18 cities in 2004. This is a significant development that is indicative of the popularity of these home-grown networks. As noted earlier, the tiered level of access affords different network privileges in connection with different user fees. In 2007, over 721,000 of the 1.6 million home-grown network members were enjoying full network privileges including Internet access while the rest were content to enjoy the other network resources (e.g., chat, file downloads, games) and refrain from Internet access in return for lower network access fees (retele.net 2007).
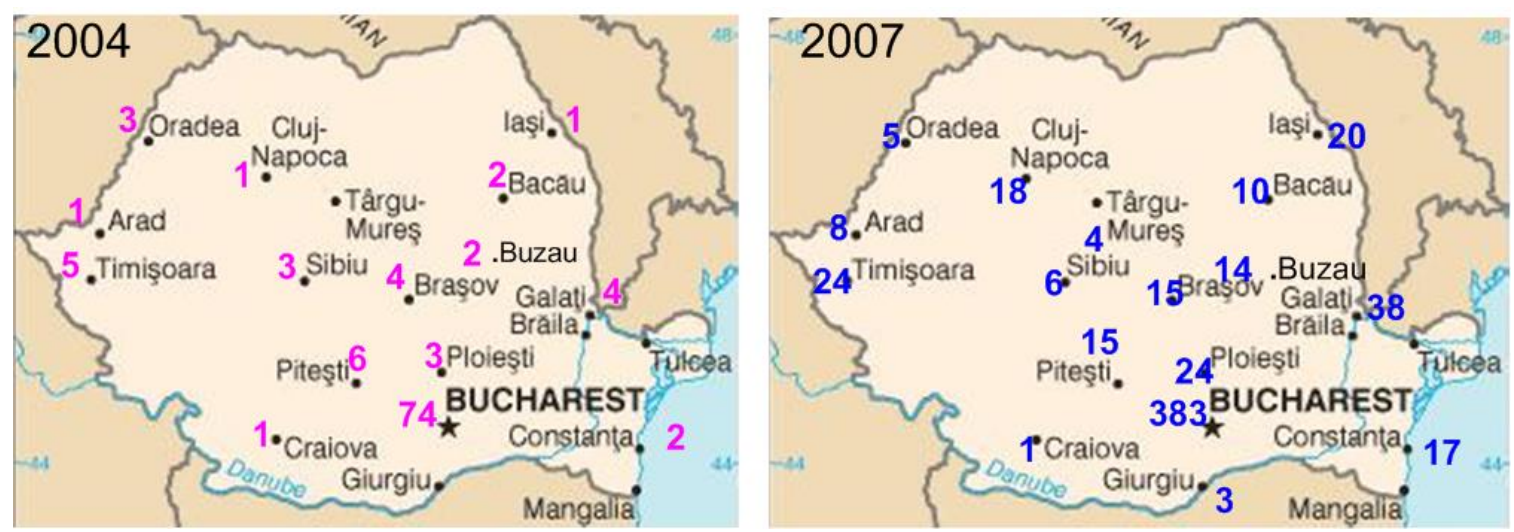

Figure 3. Home-grown networks in several major cities: 2004 vs. 2007.

The map in Figure 3 shows the rapid expansion of the home grown networks from 2004 to 2007. The un-even spread of these home-grown networks is evident and, as expected, they are concentrated in cities. Bucharest, the capital city, has the largest number of these networks. In contrast, the other cities have only a few networks each. 
A basic tenet of Diffusion of Innovation theory is that in the early stages of the diffusion process, ideas are adopted very slowly; the rate of adoption increases quickly as adopters share their favourable experiences with potential adopters. Graphically, this translates into an "S"-shaped adoption curve: the adoption rate is relatively low initially, then it increases significantly, only to level off later on as less adopters embrace the innovation (Backer and Rogers 1998). Given the 600\% increase in the number of home-grown networks from 2004 to 2007 reported earlier, it is conceivable that the phenomenon has reached critical mass. Hence, its dramatic increase in adoption rate. The most recent reports place Romania's population at 22 million (CIA 2007) and the Internet penetration rate at 23.4\% (Internet World Stats 2007).These figures compute to approximately 5.2 million users, of which as many as 1.6 million are members of a home grown network (retele.net 2007). This data, viewed in conjunction with the categories of adopters posited by Rogers and Scott (1997) would suggest the adoption rate has reached $31 \%$, indicative of an early majority (Figure 4 ). However, the precise position on the S-curve can only be determined in a subsequent study and would require additional data.

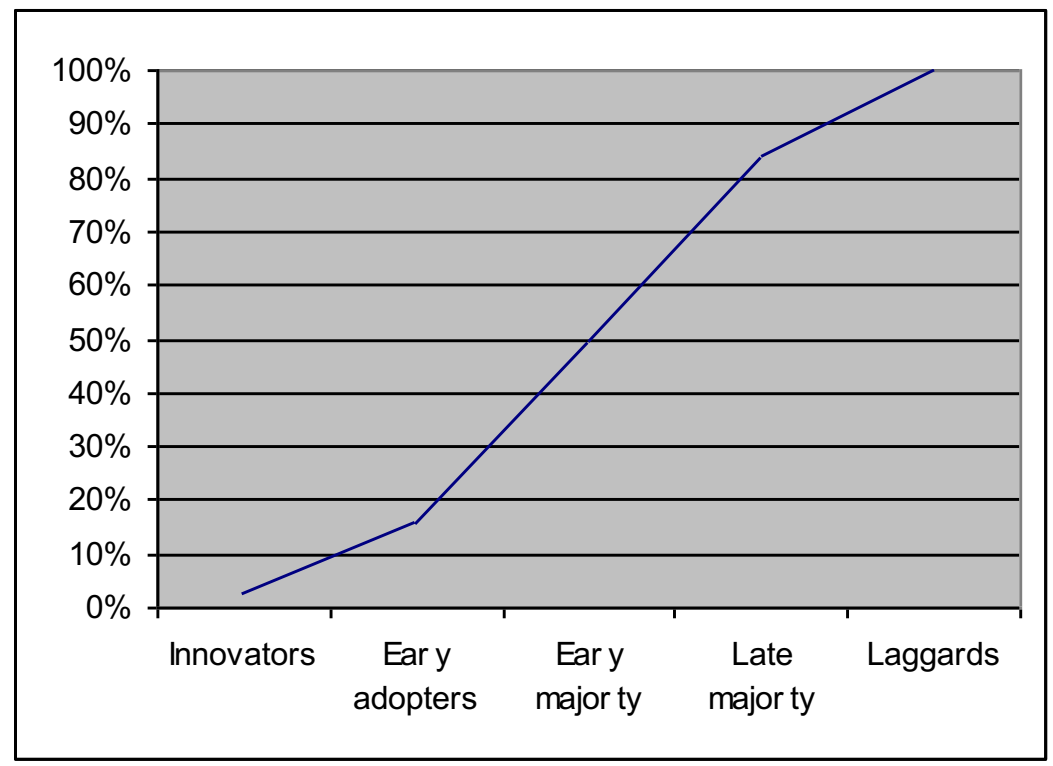

Figure 4. Home grown network adoption rate.

In terms of technology, the home grown networks discussed above offer Internet access via fast connections (from kbps to Mbps) over fibre or dedicated circuits. Yet, some of them simply share broadband accounts over cable. While the costs may be placed in the vicinity of dial-up service (the average cost seems to be around 300,000 lei, which is equivalent to approximately $\$ 10.00$ ), users certainly receive more value: they can have access to a high-speed Internet connection now, and to additional services such as chat, online games, and downloads. It is notable that network connectivity is provided via either wired Ethernet at $100 \mathrm{Mbps}$, or wireless - employing 802.11a, 802.11b, and 802.11g IEEE standards. While for many years a technology laggard in terms of networking technologies, Romania is now seeing the latest technologies being put to good use.

A home-grown network will typically provide information regarding Internet access performance as a set of three numbers (Appendix A). First, the Internet connection speed varies across these networks from $16 \mathrm{Kbps}$ for the slowest one, to $10 \mathrm{MBps}$ for the fastest one. A second number indicates the connection speed on the metropolitan network - that is the ISP's internal network. This typically is higher, around $512 \mathrm{Kbps}$ on average. Yet, one of the networks states $200 \mathrm{MBps}$ on the metropolitan network, using two different ISPs. The third number indicates the speed of the home-grown network. Network connectivity is overwhelmingly $100 \mathrm{MBps}$. Some networks also allow wireless access over 802.11 standards $\mathrm{a}, \mathrm{b}$, and $\mathrm{g}(54 \mathrm{MBps})$. As at the time of the study the $802.11 \mathrm{~g}$ wireless equipment was just beginning to take off in the USA, this was a surprising finding. Furthermore, given the economic conditions in Romania, the researcher was expecting the home grown networks to consist of 
mainly used or refurbished equipment. While this was true in some cases, for the most part, as it can be seen in Appendix A, network speeds of 100 MBps were quite common. This deployment and use of current technologies (by Western standards) is quite interesting. It appears that as funds in excess of the ISP monthly fees become available, the monies would be spent on upgrading the network. Consequently, it becomes easier to attract new members/users and the higher bandwidth offers better levels of service to all network users. The interview data supports this assertion.

A two-tier pricing scheme is prevalent among the existing home grown networks, with one fee for network and Internet access and a lower fee for network-only access. The typical home-grown network has 30-50 subscribers. Yet, membership ranges from two subscribers in the case of new, un-established networks to some 1,200 for the largest one. It is very common to see the number of Internet access subscribing member being lower than the total number of members in the particular network/co-op. Once again, the laws of economics seem to prevail over one's desire to surf the Internet.

\section{Comparison to other European countries}

Overall, in comparison to what is available in other European countries, accessing the Internet from Romania continues to cost more, and offer less value. Furthermore, given the relatively low per capita income, accessing the Internet is not an affordable proposition for everyone. As it stands today, not everyone can afford to surf the Internet in Romania. This may be one of the main reasons behind the occurrence of the home-grown networks described in the previous section, and it may explain the popularity of the Internet cafés. Table 6 offers a cursory view of the fees and types of Internet access plans available in other European countries, and for comparison, in the USA (Munteanu 2004).

Given the average monthly wage of around $€ 150$ (approximately $\$ 190$ ), it is fairly easy to see why Internet access continues to be a challenge for the average Romanian citizen (The Malta Financial and Business Times 2003; Database Central Europe 2004; Sofia News Agency 2004).

Table 6. Internet Access in Other European Countries

\begin{tabular}{|c|c|c|c|c|c|c|c|c|}
\hline Country & ISP & Plans & Download & Upload & Traffic & Cost & Installation & Notes \\
\hline \multirow[t]{4}{*}{ Hungary } & Matav & Kabbelnet Hobbi & 384 kbps & $64 \mathrm{kbps}$ & unlimited & $\$ 47.15$ & $\$ 114.00$ & $\begin{array}{l}\text { Two-year } \\
\text { contract }\end{array}$ \\
\hline & & & & & & $\$ 58.80$ & $\$ 114.00$ & $\begin{array}{l}\text { No long-term } \\
\text { contract }\end{array}$ \\
\hline & & Kabbelnet Otthon & $512 \mathrm{kbps}$ & $\begin{array}{l}128 \\
\mathrm{kbps}\end{array}$ & Unlimited & $\$ 54.60$ & $\$ 114.00$ & $\begin{array}{l}\text { Two-year } \\
\text { contract }\end{array}$ \\
\hline & & & & & & $\$ 70.60$ & $\$ 80.00$ & $\begin{array}{l}\text { No long-term } \\
\text { contract }\end{array}$ \\
\hline \multirow[t]{3}{*}{ U.K. } & Telewest & & $512 \mathrm{kbps}$ & & Unlimited & $\$ 50.83$ & $\$ 85.00$ & \\
\hline & & & $1 \mathrm{Mbps}$ & & & $\$ 68.00$ & $\$ 85.00$ & \\
\hline & & & $2 \mathrm{Mbps}$ & & & $\$ 93.48$ & $\$ 85.00$ & \\
\hline \multirow[t]{5}{*}{ France } & Numericable & & $128 \mathrm{kbps}$ & & & $\$ 23.90$ & & \\
\hline & & & $512 \mathrm{kbps}$ & & & $\$ 29.90$ & & \\
\hline & & & $1 \mathrm{Mbps}$ & & & $\$ 53.90$ & & \\
\hline & & & & & & $\$ 41.40$ & & $\begin{array}{l}\text { Cable TV } \\
\text { subscriber }\end{array}$ \\
\hline & Chello & & $512 \mathrm{kbps}$ & $\begin{array}{l}128 \\
\mathrm{kbps}\end{array}$ & & $\$ 53.50$ & $\$ 108.00$ & \\
\hline \multirow[t]{3}{*}{ USA } & RoadRunner & & & & Unlimited & $\$ 44.95$ & & \\
\hline & AOL & & & & Unlimited & $\$ 44.95$ & & \\
\hline & Earthlink & & & & Unlimited & $\$ 41.95$ & & \\
\hline
\end{tabular}

The pie-charts in Figure 5 show the cost of broadband Internet access plans as a percentage of the average gross income for Romania, Hungary, U.K., France, and USA. 

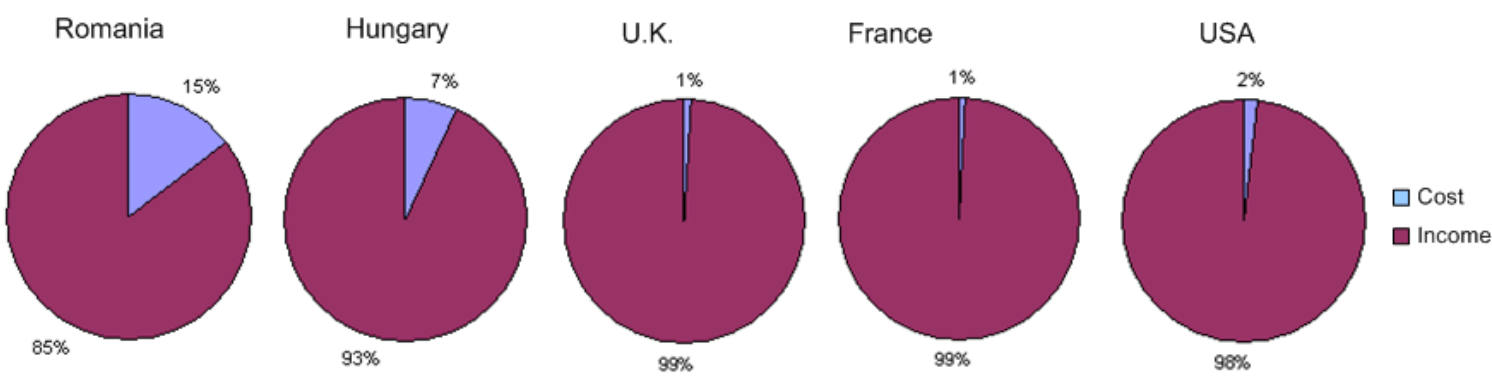

Figure 5. Comparative cost of Internet access relative to gross income

The term income as used in Figure 5 refers to average gross wages per month. After accounting for taxes and living expenses there is significantly less disposable income left for discretionary expenditures, Internet access included (Eurostat 2003).

Romanian Internet surfers may choose among the dial-up or broadband plans available in the area where they live. It may be as simple as visiting a nearby cyber café periodically. Alternatively, they may be able to join a local home-grown network that offers shared Internet access. If the option to join an existing network is unavailable, they may decide to start one of their own - either alone, or with a group of other people who are interested in this co-operative approach to Internet access. Clearly the incentive is to save money by sharing the ISP fees (and bandwidth) with others. Yet in some cases, membership in a home-grown network affords higher bandwidth, with shared broadband access rather than dial-up. The choices available vary, as access plans differ from location to location.

Cyber cafés are almost a staple, at least in the urban areas. They offer convenient and affordable Internet access for those who either cannot afford to, or do not wish to set up individual ISP accounts at their homes. In addition, for those who are either without a computer, or away from their home or office, the cyber cafés offer access to office productivity (printing, scanning, and access to general PC software applications) and Internet access for very little money.

The number of home-grown networks in the country seems to be increasing. However, this phenomenon seems limited for now to cities, where apartment buildings offer a higher population density and the physical span of the network is more manageable. Table 7 summarizes, and offers a quick comparison of some of the choices available to the would-be Internet surfer in Romania.

Table 7. Internet access choices

\begin{tabular}{|l|l|l|l|l|}
\hline & Dial-up & Broadband & Cyber café & Home-grown network \\
\hline Cost & $\$ 10.00 /$ month & $\$ 30.00 /$ month & $\$ 0.50 / \mathrm{hr}$ & $\$ 10.00 /$ month \\
\hline Speed & $20 \mathrm{kbps}$ & $128 \mathrm{kbps}$ & $128 \mathrm{kbps}$ & $256 \mathrm{kbps}$ \\
\hline Pros & $\begin{array}{l}\text { Relatively affordable; } \\
\text { suitable for chat and } \\
\text { email; convenient }\end{array}$ & $\begin{array}{l}\text { Fast; suitable for } \\
\text { multimedia; does not } \\
\text { tie up the phone line; } \\
\text { convenient }\end{array}$ & $\begin{array}{l}\text { Affordable; } \\
\text { suitable for chat } \\
\text { and email }\end{array}$ & $\begin{array}{l}\text { Relatively affordable; } \\
\text { good value; convenient; } \\
\text { local community }\end{array}$ \\
\hline Cons & $\begin{array}{l}\text { Low speed; ties-up the } \\
\text { phone line while in } \\
\text { use; additional per } \\
\text { minute charges } \\
\text { incurred for phone use }\end{array}$ & $\begin{array}{l}\text { Expensive; must pay } \\
\text { for the modem and } \\
\text { installation services }\end{array}$ & $\begin{array}{l}\text { Inconvenient }- \\
\text { must leave home; } \\
\text { privacy concerns }\end{array}$ & Not available in all areas \\
\hline
\end{tabular}

Lagging behind other developed countries, Romania is making progress in terms of Internet access. As indicated by the home-grown networks that offer shared Internet access, people are finding ingenious ways to overcome the relatively high costs of Internet access. A trait that was honed during the years of socialism, when spare parts were scarce and many times they had to be designed and manufactured in a craftsman-like manner, seems to have resurfaced. Is this mere entrepreneurship? Perhaps. However, the benefits for the Internet users participating in these shared home-grown networks are self-evident. While 
this phenomenon may be construed as an exercise in entrepreneurship, it does appear to meet the needs of the would-be urban Internet surfer in a cost-effective manner. It is undoubtedly a phenomenon worth monitoring.

\section{Lessons Learned}

It seems that under the right economic conditions, home-grown shared Internet access will eventually materialize. But, what are the "right" conditions? For one, there should be Internet service available. Once that Internet service is available in a market, it is only a matter of time until would-be users will establish co-ops. Of course, the underlying assumption is that they have personal computers available, and the desire to surf the Internet - cost being the single most important obstacle they face.

What can governments do to encourage Internet surfing? The single most important thing is to take care of the infrastructure. That means ensuring the power grid is functional, and that telecommunication resources are in place. It is hardly fathomable to expect people to use personal computers without access to electric power, and it is impossible to connect to the Internet without an ISP. The second most important element needed to facilitate this phenomenon is the existence of ISPs. This role can be fulfilled by either a for-profit, non-profit, non-governmental, or governmental organization. Governments can provide incentives to encourage ISP start-up companies.

The co-op phenomenon allows for building up an Internet user base much faster than otherwise possible. The ISPs should consider encouraging this phenomenon as it is likely to help rapidly add Internet users. One way ISPs can encourage this is by offering high speed modems or perhaps offer to handle the billing for co-ops.

While it is important for ISPs to allow this behaviour, it is not entirely clear whether they have efficient means from preventing this - other than legal provisions and service policies. As any account holder can resort to network address translation in order to connect a private LAN to the Internet, it is unlikely the ISP can do much to block and/or filter traffic.

One possible trend that can occur is that as time progresses and prices start to drop, some co-op users will seek to build their own co-ops. Another trend may be that they will choose to surf the web on their own, and sign up for personal ISP accounts. This would allow them to achieve even greater bandwidth than through the co-op and perhaps, access to a larger variety of services offered by the ISP. Therefore, a likely trend is from expensive to cheaper access and from lower to higher bandwidth, while continuing to increase the number of Internet users and of ISP customers in the same time.

In time, as the Internet users become more sophisticated, their economic wherewithal and personal interests may lead them down this path, or not.

\section{Future Research}

A number of potential research opportunities are available to either confirm or expand the findings of this study. First, a longitudinal study along the same lines with the one presented here, would provide some interesting data on whether the findings reported here will continue to hold over time, and the evolution of these home-grown networks and co-operative Internet access. Second, the study could be extended to include the country-side, where the population density is inherently lower than in the urban areas to find out more about how non-urbanites connect to the Internet. Third, further research may be conducted to investigate other countries that face similar economical challenges, in order to learn more about the Internet access choices their populations have. A cross-countries study would be another possibility. Continuing in the direction of this study, a follow up study involving quantitative methodologies would help inform on the degree of penetration of various Internet access technologies and on the extent to which the home-grown networks identified by this study continue to evolve and grow. Such study may bring additional confirmatory evidence in support of, and furthering the importance of this study. 


\section{Conclusion}

The study presented here achieved its goals of exploring the connectivity options available to the Romanian would-be Internet surfer and to find out whether the economic and technological hindrances characteristics of a developing country - can be circumvented, and if so, in what manner.

The findings of the study are of interest to academic researchers and practitioners alike. The analysis of the various Internet access choices available in the country is thorough and informative. The Internet cafés studied and the discussion of shared Internet access solutions are applicable to other developing countries. And last, this report would be of interest to those who want to get into the ISP business in Romania, or wish to relocate there and carry on an Internet-enabled business or want to approach the Romanian market via the Internet.

This study set to explore Internet access in a developing country. Among its findings, the co-operative approach to Internet access stands out as an innovative, affordable solution to mitigating the relatively high cost of connecting to the Internet. As this study indicates, this type of development appears to be unique to the setting of the study and has not been found or reported elsewhere. Understanding the context within which home-grown networks arise and prosper offers valuable information that can be transferred to other developing countries. The same can be said about the very approach, which is to allow would-be Internet users to pool their resources and split the cost of Internet access over a shared local area network they build.

Home-grown Internet access is a useful solution for the near term, yet one cannot expect the situation to stay the same forever. In Romania, like in any other country, the Internet access fees may eventually become more affordable. While this is by no means a certainty, it is conceivable that as technology costs continue to drop and incomes continue to rise, the home-grown networks will probably - but not certainly - be supplanted. However, at least for the time being, these home-grown networks appear to continue to spread.

Romania is making steady progress toward a fully functional market economy, and access to the Internet is becoming more and more affordable. Yet, it will take some time for this type of service to become truly affordable. As it stands, the ingenuity of the average citizen continues to find ways around this problem. Therefore, at least for the near future, this co-operative approach to Internet access can be expected to continue. After all, it does seem to offer better value to the consumer.

\section{Notes and Acknowledgments}

The researcher would like to acknowledge the contribution of the Internet users who agreed to participate in the study, and the useful comments and suggestions offered by other researchers and outside readers. An emergent, early version of this paper was presented at the 2005 Annual Conference of the Southern Association of Information Systems.

\section{References}

Afla ro (2007). 'Internet Café.' (02/09/2007). http://www.afla.ro?/d-internet\&sd=internet+cafe

ANISP Romania (2003). 'ANISP presentation 10/21/2003.' (09/07/2004). http://www.anisp.ro/?c=noutaticomunicate\&...\&PHPSESSID $=\mathrm{a} 56 \mathrm{f0da9e} 760 \mathrm{f6eb} 06 \mathrm{f} 3 \mathrm{e} 3 \mathrm{db} 872 \mathrm{~d} 8 \mathrm{~d} 5 \mathrm{~d}$

Backer, T. E. and E. M. Rogers (1998). 'Diffusion of Innovations Theory and Work-Site AIDS Programs.' Journal of Health Communication 3: 17-28.

BBC Monitoring European - Political (2001). 'Romania: Communications minister announces steps toward "eRomania”.' BBC Monitoring European - Political, London, Jun 6, 2001, 1.

BBC Monitoring Media (2000). 'Romania: Internet monthly growth averages 10 per cent.' BBC Monitoring Media, London, May 25, 2000, 1.

Budd, J. (2003). 'IDC: Internet penetration in Central and Eastern Europe to reach 17\% in 2003, says IDC.' M2 Presswire, Feb 18, 2003, 1.

Business Eastern Europe (2002). 'Web watch.' Business Eastern Europe, London, UK, August 5th 2002, 
Business Wire (1998). 'Cisco and BreezeCOM Win Major Romanian Higher Education Network Contract.' Business Wire, New York, Jul 23, 1998, 1.

Business Wire (2004). 'Research and Markets: 2004 Telecoms in Europe - The Balkans and the South East: Internet and Mobile Penetration Rates low.' Business Wire, New York: May 14, 2004, 1.

Business Wire (2004). 'Research and Markets: An Examination of Past, Current and Future Demand for Broadband Equipment and Services in 29 Leading European Countries.' Business Wire, New York: Sep 23, 2004, 1.

Chandler, R. (2002). 'Online: Second sight: Digital divide racism's new frontier.' The Guardian, Manchester (UK), Jan 17, 2002, 2.

Chronicle, H. (2001). 'Geeks join geezers to cut nations' technology gap.' Houston Chronicle, Houston, Tex., Aug 14, 2001, 4.

CIA (2004). 'The World Factbook - Romania.' http://www.cia.gov/cia/publications/factbook/print/ro.html

CIA (2007). 'The World Factbook.' (June 6, 2007). https://www.cia.gov/library/publications/the-worldfactbook/index html

Cybercafes.com (2007). 'Internet cyber cafes guide all over the world.' (02/09/2007). http://www.cybercafes.com/continent.asp?continent=Europe

DAP (2004). 'Retele Locale de Calculatoare.' (11/08/2004). http://retele.dap.ro

Database Central Europe (2004). 'Average Gross Monthly Wages.' (11/22/2004). http://www.databasece.com/wagegross htm

EuropeMedia (2002). 'Cheaper internet services expected in 2003.' Europemedia, Amsterdam: Dec 9, $2002,1$.

EuropeMedia (2003). '50m internet users in the new EU countries by 2007.' Europemedia, Amsterdam: Jun 10, $2003,1$.

Eurostat (2003). 'Minimum Wages - EU Member States and Candidate Countries, January 2003.' (11/22/2004). http://europa.eu.int/comm/eurostat/newcronos/reference/

Eurostat (2004). 'Eurostat Yearbook 2004 - The Statistical Guide to Europe.' (11/22/2004). http://epp.eurostat.cec.eu.int

Goodman, S. E. (1991). 'From Under the Rubble: Computing and the Resuscitation of Romania.' Communications of the ACM 34(9): 19-22.

Gurau, C. (2002). 'Online banking in transition economies: The implementation and development of online banking systems in Romania.’ The International Journal of Bank Marketing 20(6): 285.

Home ro (2004). 'Site-uri Web.' (11/22/2004). http://www.home.ro/dir/107

Ignatius, D. (2002). 'Europe's Real Modernizers.' The Washington Post, Washington, D.C.: Dec 13, 2002 , A45.

IMF (2006). 'World Economic Outlook. Financial Systems and Economic Cycles.' September 19, 2006, http://www.imf.org/external/pubs/ft/weo/2006/02/index htm, 296.

Internet World Stats (2007). 'Internet Usage in the European Union.' (01/25/2007). http://www.internetworldstats.com/stats9.htm\#eu

Internet World Stats (2007). 'Top 35 countries with the highest Internet penetration rate.' http://www.internetworldstats.com/top25.htm

Jalobeanu, M. (2003). 'Romania pe Net.' (09/07/2004). http://www.itim-cj.ro/ jalobean/Romania pe net html

Johnson, A. K. (1999). 'Globalization from below: Using the Internet to internationalize social work education.' Journal of Social Work Education 35(5): 377.

Ladika, T. (2004). 'EU Internet Access Lags Behind U.S.' Wall Street Journal, Brussels: Jul 14, 2004, A2.

LearnLink (2002). 'Roumanie - Rattraper des decennies perdues.' (09/07/2004). http://learnlink.aed.org/Publications/Country Papers/cp pdf/FR CP Romania.pdf

M2 PressWire (2002). 'UN: 'Digital divide' still yawns as widely as ever, says secretary general, as general assembly opens two-day session on information technologies; Senegal's President cites hopeful signs of 'digital revolution' for Africa; Speakers say new technologies must be used to reach millennium development goals; Part 2 of 3”,,' M2 Presswire, Coventry, Jun 18, 2002, 1.

M2 PressWire (2003). 'ITU: Path towards information society for all takes shape; Declaration and action plan outlined.' M2 Presswire, Coventry, Mar 3, 2003, 1.

M2 PressWire (2003). 'Research and Markets: Recent Internet and mobile penetration rates decreasing in Balkan and South east European States.' M2 Presswire, Coventry: Nov 13, 2003, 1.

MacAonghus, J. (2004). 'Online impact of a growing Europe.' New Media Age, London: Feb 12, $2004,15$.

Munteanu, A. B. (2004). 'Connectare Cablu.' (09/07/2004). http://www.geocities.com/muntealb/ConectareCablu-bn htm

Munteanu, A. B. (2004). 'Costul Internet in Romania.' (09/07/2004). http://www.geocities.com/muntealb/CostInternetRo-bn.htm 
Norris, P. (2000). 'The Global Divide: Information Poverty and Internet Access Worldwide.' (11/22/2004). http://www.ksg.harvard.edu/iip/governance/psa2000dig.pdf

Noua Economie (2002). 'Revolutia Internet - Situatia din Romania.' (09/07/2004). http://www.crie.ro/nouaeconomie/sr1231-situatia-VD html

Oaca, N. (2000). 'Romania: Wireless Spurs Telecoms Growth.' Telecommunications 34(4): 92.

OxResearch (2002). 'BALKANS: Region offers home for knowledge industries.' OxResearch, Oxford, May 10, $2002,1$.

Panait, L., C. R. Doarn, et al. (2004). 'A Review of Telemedicine in Romania.' Journal of Telemedicine and Telecare 10(1): 1 .

retele.net (2007). 'Retele de bloc si cartier.' (02/05/2007). www.retele net

Rocks, D. (1998). 'There's no shortage of information about Central Europe on the Internet: The trick is spotting what's useful.' The Wall Street Journal (Europe), Brussels, Apr. 27, 1998, 18.

Rogers, E. M. (1995). Diffusion of Innovations. New York, The Free Press.

Rogers, E. M. and K. L. Scott (1997). 'The Diffusion of Innovations Model and Outreach from the National Network of Libraries of Medicine to Native American Communities.' (June 11, 2007). http://nnlm.gov/archive/pnr/eval/rogers.html

RomaniaBusiness.com (1997). 'Romania Business.' http://www romaniabusiness.com

Romania-On-Line (2007). 'Internet Café.' (02/09/2007). http://romania-on-line netr/general/internetcafe.htm

Sofia News Agency (2004). 'Bulgaria, Romania - Europe’s Wage Laggards.' (11/22/2004). http://www.novinite.com/newsletter/print.php?id=37581

Tarifica Alert (2004). 'Romania - Breakdown of telephony service providers in Romania.' Tarifica Alert, Potomac: Aug 24, 2004, 1.

Tarifica Alert (2005). 'Romania - Internet penetration on the increase in Romania by 51.48 percent.' Tarifica Alert: Potomac, Jan 4, 2005, 1.

Telelucru (2004). 'Tendinte.' (11/22/2004). http://telework.bravepages.com/marketing/perspectivetendinte htm

The Age (2006). 'Gates Foundation to provide free access to computers and Internet in Romania.' (02/05/2007). http://www.theage.com.au/news/Technology/Gates-Foundation-to-provide-free-access-tocomputers-and-Internetin-Romania/2006/11/24/1163871584295.html

The Electronic Library (2001). 'The Information Society.' The Electronic Library, 268.

The Electronic Library (2001). 'The Information Society.' The Electronic Library, 57.

The Malta Financial and Business Times (2003). 'FOI deems national wages policy a 'growing concern'.' The Business Times, June 11, 2003,

Woodard, C. (1995). 'Transylvania Goes On-Line With Internet.' Christian Science Monitor, Boston, Mass., Apr 27, 1995, 1.

World66.com (2007). 'The travel guide you write.' (02/09/2007). http://www.world66.com/europe/romania/bucharest/internetcafes

Yin, R. K. (1994). Case Study Research: Design and Methods. Thousand Oaks, CA, Sage Publishing. 
Appendix A: Home-grown Networks (DAP, 2004)

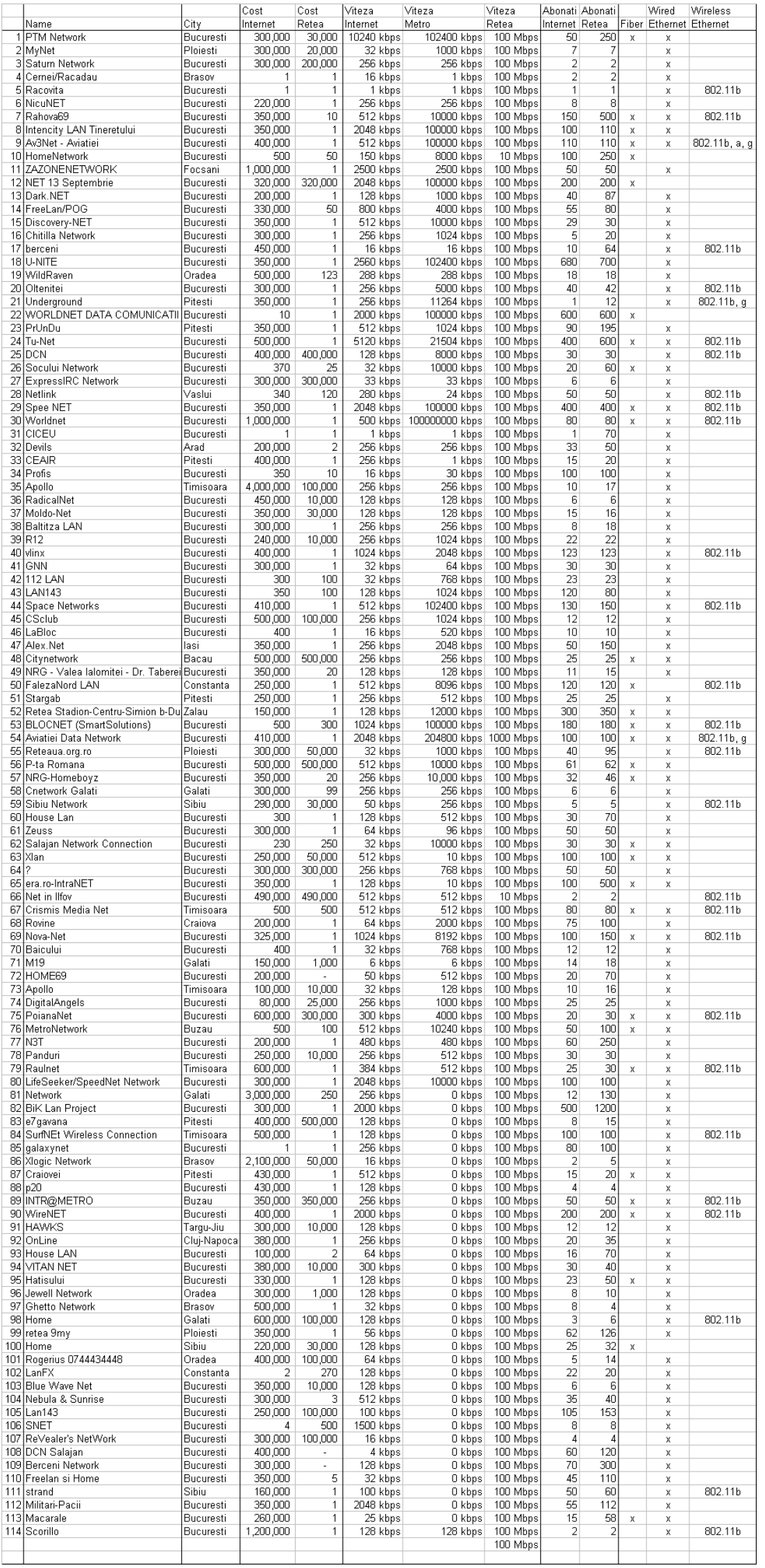


